\title{
LITERASI INFORMASI PETANI NANAS DALAM MENINGKATKAN PRODUKTIVITAS PERTANIAN DI DESA TANGKIT BARU KEC. SUNGAI GELAM KAB. MUARO JAMBI
}

\author{
Andi Junudu ${ }^{1}$, Muhammad Rum ${ }^{2}$, Wenny Dastina ${ }^{3}$ \\ ${ }^{1,2,3}$ UIN Sulthan Thaha Saifuddin Jambi \\ andijunudusweet27@gmail.com
}

\begin{abstract}
This article discusses the pineapple farmer's literacy in improving agricultural productivity in the Tangkit Baru Village. The Purpose of this article was to explore the literacy level of farmer information by default of The International Federation of Library Association and Literacy (IFLA). The writing employed a descriptive qualitative method with a sampling approach. The data analysis technique used is the flow model of data reduction, data presentation and deduction scheme. The results proved that the pineapple farmers' literacy in the village of Tangkit Baru in good category, with increased productivity. The default IFLA information literation component suggest, (information access) is obtained through socialization among farmers, as well as through generations; then at the rate (information evaluation), farmers know the variety of plants, the inhibitory factors dof locating information, and the ability to compare the information accordingly are evaluated so that information can be useful; and (use of information), farmers apply information through experimentation and information obtained, disseminated and communicated to create coexistence. The pineapple farmers in the Tangkit Baru village at the average level of secondary school are able to work well, because of the important information literacy role of their communities. Which, of course, the pineapple productivity will increase as well as minimize the damage to the farmland.
\end{abstract}

Keywords: Literacy of Information, Pineapple Growers, Agricultural Productivity

\section{ABSTRAK}

Artikelini membahas Literasi Petani Nanas dalam meningkatkan produktivitas pertanian di Desa Tangkit Baru. Tujuan penulisan artikel ini adalah mengeksplor tingkat Literasi Informasi Petani dengan standar literasi International Federation of Library Association and Institutions (IFLA). Penulisan ini menggunakan metode kualitatif deskriptif dengan pendekatan purposive sampling. Teknik analisis data yang digunakan adalah skema Flow Modelyakni Reduksi Data, Penyajian Data serta Penarikan Kesimpulan. Hasilnya membuktikan bahwa literasi petani nanas di Desa Tangkit Baru berada pada kategori baik, sehinggaproduktivitasnya meningkat. Dari komponen standar Literasi Informasi IFLA menunjukkan, (akses informasi)diperoleh melalui sosialisasi antar petani, serta secara turun temurun; kemudian tingkat(evaluasi informasi),petani mengetahui jenis tanaman nanasnya, faktor 
Andi Junudu, Muhammad Rum, Wenny Dastina: Literasi Informasi Petani Nanas

dalam Meningkatkan Produktivitas Pertanian di Desa Tangkit Baru Kec. Sungai Gelam

Kab. Muaro Jambi

penghambat mencari informasi, serta mampu membandingan informasi yang didapat seterusnya dievaluasi sehingga informasi dapat bermanfaat; dan(penggunaan informasi), petani menerapkan informasi dengan percobaan terlebih dulu serta informasi diperoleh,disebar dan dikomunikasikan untuk menimbulkan kebersamaan gotong royong.

Kata Kunci:Literasi Informasi, Petani Nanas, Produktivitas Pertanian

\section{PENDAHULUAN}

Kecerdasan dalam memahami suatu kebutuhan, mencari sumber referensi, mendapatkan, mengevaluasi, dan mengolah sebuah informasi yang dimiliki adalah bentuk dari literasi informasi. Literasi informasi dapat diartikan sebagai rangkaian kemampuan yang dibutuhkan seseorang untuk memahami suatu kebutuhan yang kapan seharusnya informasi tersebut digunakan dan bagaimana menemukannya, mengevaluasi dan juga menggunakan suatu informasi yang dibutuhkan secara efektif dan efisien.Literasi sendiri secara sederhana dapat diartikan sebagai kemampuan membaca dan menulis. Dalam konteks pemberdayaan masyarakat, literasi mempunyai arti kemampuan memperoleh informasi dan menggunakannya untuk mengembangkan ilmu pengetahuan yang bermanfaat bagi masyarakat. (Susdanwari, 2018:21) Pengembangan ilmu pengetahuan yang bermanfaat ini, bila secara terus menerus dilakukan akan menjadikan proses belajar sepanjang hayat. Karena upaya dalam proses belajar sepanjang hayat yang nantinya akan menjadikan sebuah acuan seseorang dalam mencari dan menemukan informasi dengan baik.Menurut Davis dalam Abdul kadir menyatakan, "Informasi adalah data yang telah diolah menjadi sebuah bentuk yang berarti bagi penerimanya dan bermanfaat dalam pengambilan keputusan saat ini atau saat mendatang". (Kadir, 2003:27) Data yang telah diolah dan memiliki pesan yang bermanfaat untuk orang yang menerimanya juga dari hasil sebuah kesaksian dari orang yang menyaksikan sebuah peristiwa, kesemua itulah yang di maksud dengan informasi.

Laporan UNESCO tahun 2005 berjudul literacy for life dalam Meidawati Suswandarimenyebutkan bahwa "Ada hubungan erat antara illiteracy 
Andi Junudu, Muhammad Rum, Wenny Dastina: Literasi Informasi Petani Nanas

dalam Meningkatkan Produktivitas Pertanian di Desa Tangkit Baru Kec. Sungai Gelam

Kab. Muaro Jambi

(ketidakberakasaraan) dan kemiskinan. Di banyak Negara berangka kemiskinan tinggi seperti Bangladesh, Ethiopia. Ghana, India, Nepal, dan Mozambique, tingkat illiteracy-nya juga tinggi." (Susdanwari, 2018:27) Tidak menutup kemungkinan bila ini di implementasikan kepada para petani. Tentunya kemampuan literasi informasi yang didapatkan oleh para petani dapat mempemudah memahami, mengevaluasi tata cara bercocok tanam dengan baik, mengolah dan memasarkan hasilnya. Sehingga kemudahan, pemahaman, pengevaluasian dalam bercocok tanam dapat dirasakan menyeluruh oleh seluruh lapisan masyarakat dibandingkan dengan petani yang tidak mengerti dengan literasi informasi.

Hampir seluruh penduduk desa Tangkit Baru Kecamatan Sungai Gelam menggunakan lahannya untuk bercocok tanam nanas. Merujuk kepada Matrik Desa Tangkit Baru dalam Tangkit Baru Membangun (2017), Luas wilayah Desa Tangkit Baru adalah 1.811,2 Ha/bujur sangkar. Pada zona I seluas 1.185 Ha. (Andi, 2020:8-9) digunakan untuk menanam buah nanas yang cita rasanya manis keasam-asaman, serta berbentuk lonjong bersisik, dan berwarna kuning ketika matang.Melalui SK Menteri Pertanian No.103/kpts/TP.2004/3/2000 pada tahun 2000, nanas yang berada di Desa Tangkit Baru ditetapkan sebagai suatu komoditi unggulan dari Provinsi Jambi dan diberikan nama "Nanas Varietas Tangkit" serta termasuk dalam golongan Nanas Queen.

Masyarakat Desa Tangkit Baru pada umumnya adalah masyarakat yang berpendidikan SLTP/SMP sederajat yang sesungguhnya pemahaman terhadap budidaya pertanian sektor buah nanas masih rendah. Apalagi dikaitkan dengan teknologi pertanian, terlihat jelas bahwa petani masih sangat jauh terhadap pengetahuan pertanian. Akan tetapi, fakta dilapangan menunjukkan masyarakat justru sukses dalam mengembangkan budidaya nanas. Kondisi ini menyebabkan Desa Tangkit Baru menjadi sentra komoditi buah nanas terbesar di Provinsi Jambi.Adapun tujuan dari penulisan artikel ini adalah Untuk mengetahui kemampuan literasi 
Andi Junudu, Muhammad Rum, Wenny Dastina: Literasi Informasi Petani Nanas

dalam Meningkatkan Produktivitas Pertanian di Desa Tangkit Baru Kec. Sungai Gelam

Kab. Muaro Jambi

informasi petani nanas di Desa Tangkit Baru dalam mengakses, mengevaluasi, serta menggunakan informasi dalam meningkatkan produktifitas pertanian.

\section{KAJIAN TEORI}

\section{PENGERTIAN LITERASI INFORMASI}

Agustian Widya Gunawan menggambarkan Literasi informasi adalah suatu kemampuan belajar terus-menerus secara mandiri dan untuk berkomunikasi. Literasi informasi adalah serangkaian kemampuan dan keterampilan seseorang untuk menyadari kebutuhan informasi dan kapan informasi itu diperlukan, mengidentifikasi dan menemukan informasi yang dibutuhkan, memanfaatkan secara efektif, legal dan etis serta mengkomunikasikannya." (Gunawan, dkk, 2018:2) Lainnya, Rhoni Rodin mendefinisikan literasi informasi sebagai seperangkat kemampuan yang diperlukan individu untuk mengenali kapan informasi dibutuhkan dan memiliki kemampuan untuk menemukan, mengevaluasi, dan menggunakan informasi yang dibutuhkan secara efektif. (Rodin, 2016:83)

Literasi informasi juga yang sering disebut kemelekan informasi. Dalam bidang ilmu perpustakaan dan informasi, literasi sering dikaitkan dengan kemampuan mengakses, mengidentifikasi dan menggunakan informasi serta mampu memanfaatkan informasi secara benar terhadap informasi yang tersedia. Dengan adanya kemampuan literasi yang dimiliki oleh seseorang dapat membantu dalam menemukan sumber-sumber informasi yang dibutuhkan sehingga seseorang dapat secara langsung mengetahui dan menggunakan informasi secara efektif dan efisien serta dapat mengidentifikasi sebuah informasi yang ditemukan.

Kemampuan untuk menemukan informasi, mengolah dan menyajikan informasi sebenarnya kemampuan umum yang dimiliki oleh setiap orang. Tetapi tidak semua orang dapat dikatakan mempunyai keterampilan literasi informasi mampu memahami kebutuhan informasi dan mendapatkan informasi yang tepat dalam berbagai format, lalu mampu menggunakan dan menyajikan informasi tersebut dalam bentuk yang tepat dan benar. Dengan kemampuan ini seseorang memiliki 
Andi Junudu, Muhammad Rum, Wenny Dastina: Literasi Informasi Petani Nanas

dalam Meningkatkan Produktivitas Pertanian di Desa Tangkit Baru Kec. Sungai Gelam

Kab. Muaro Jambi

kerangka kerja intelektual untuk memahami, mencari dan mengevaluasi serta menggunakan informasi.

Menurut Ummi Rodiyah menyatakan bahwaLiterasi informasi yang mengacu pada kemampuan membaca dan menulis tampaknya tidak sesuai lagi bila disandingkan dengan konteks sekarang di era teknologi dan informasi. Graff mendefinisikan literasi sebagai kemampuan untuk membaca dan menulis. Menurut kamus Oxford, definisi (lama) literasi adalah kemampuan membaca dan menulis. (Rodiyah, 2017:230)

Mengenai literasi informasi ada beberapa defenisi menurut para ahli dan lembaga. Konsep literasi informasi untuk pertama kali diperkenalkan pada tahun 1974 oleh G. Zurkowki, pimpinan dari informasi industry association. Menurutnya orang yang terlatih menggunakan informasi dalam pekerjaan mereka disebut juga orang yang melek informasi.

Ada beberapa komponen literasi yang dapat mendukung literasi informasi, diantaranya:

\section{a. Literasi perpustakaan (Library literacy).}

Literasi perpustakaan membantu seseorang untuk menjadi pengguna yang mandiri perpustakaan dan mampu untuk menetapkan, menempatkan, mengambil, dan menemukan kembali informasi dari perpustkaan.

\section{b. Literasi visual (visual literacy).}

Diartikan sebagai kemampuan untuk memahami dan menggunakan gambar, termasuk kemampuan untuk berfikir, belajar dan menjelaskan istilah yang digambarkan. (Nasution, 2010:1)

\section{c.Literasi media (media literacy).}

Dalam hal ini literasi media merujuk kemampuan khalayak yang melek terhadap media dan pesan media massa dalam konteks komunikasi massa. (Tamburaka, 2013:7)

\section{d. Literasi komputer (computer literacy).}


Andi Junudu, Muhammad Rum, Wenny Dastina: Literasi Informasi Petani Nanas

dalam Meningkatkan Produktivitas Pertanian di Desa Tangkit Baru Kec. Sungai Gelam

Kab. Muaro Jambi

Secara umum diartikan sebagai perangkat komputer dan mampu menciptakan serta memanipulasi dokumen, dan akrab dengan email juga internet.

e. Literasi jaringan (network literacy).

Adalah kemampuan untuk menentukan lokasi akses dan menggunakan informasi dalam lingkungan jaringan pada tingkat nasional, regional dan internasional.

\section{TUJUAN DAN MANFAAT LITERASI INFORMASI}

\section{a. Tujuan Literasi Informasi}

UNESCO menyatakan bahwa tujuan literasi informasi sebagai berikut:

1) Memberikan keterampilan seseorang agar mampu mengakses dan memperoleh informasi mengenai kesehatan, lingkungan, pendidikan, pekerjaan mereka, dan lain-lain.

2) Memandu mereka dalam membuat keputusan yang tepat mengenai kehidupan mereka.

3) Lebih bertanggung jawab terhadap kesehatan dan pendidikan mereka. (Septiyantono, 2019:1)

Menurut A. Mentari Tujuan dari literasi informasi ini adalah mengetahui bagaimana meng- organisasikan informasi, bagaimana menemukan informasi dan memanfaatkan informasi sebagai modal untuk pendidikan seumur hidup. Hal inilah yang menyebabkan literasi sangat penting bagi masyarakat baik sosial, ekonomi, politik, budaya dan pendidikan. (Mentari, 2014:3) Berdasarkan tujuan diatas, literasi informasi ditujukan untuk membantu seseorang dalam memenuhi kebutuhan informasinya, baik untuk kehidupan pribadi, pekerjaan, maupun lingkungan sosial masyarakat.

\section{b. Manfaat Literasi Informasi}

Menurut Adam ada beberapa manfaat literasi informasi, yaitu:

1) Membantu mengambil keputusan 
Andi Junudu, Muhammad Rum, Wenny Dastina: Literasi Informasi Petani Nanas

dalam Meningkatkan Produktivitas Pertanian di Desa Tangkit Baru Kec. Sungai Gelam

Kab. Muaro Jambi

Literasi informasi berperan dalam membantu memecahkan suatu persoalan. Kita harus mengambil keputusan tersebut seseorang harus memiliki informasi yang cukup.

2) Menjadi manusia pembelajar di era ekonomi pengetahuan.

Kemampuan literasi informasi memiliki peran yang sangat penting dalam meningkatkan kemampuan seseorang menjadi manusia pembelajar. Semakin terampil dalam mencari, menemukan, mengevaluasi dan menggunakan informasi, semakin terbukalah kesempatan untk selalu melakukan pembelajaran sehingga dapat belajar secara mandiri.

3) Menciptakan pengetahuan baru

Suatu Negara dapat dikatakan berhasil apabila mampu menciptakan pengetahuan baru. Seseorang yang memiliki literasi informasi akan mampu memilih informasi mana yang benar dan mana yang salah, sehingga tidak mudah saja percaya dengan sumber informasi yang diperoleh. (Website Pshycology, 2019)

Menurut Hancock manfaat literasi informasi adalah:

\section{1) Untuk pelajar}

Pelajar dan guru akan dapat menguasai pelajarna merakan dalam proses belajar mengajar dan siswa tidak akan tergantung kepada guru karena dapat belajar secara mandiri dengan kemampuan literasi informasi yang dimiliki. Hal ini dapat dilihat dari penampilan dan kegiatan mereka dilingkunhgan belajar. Mahasiswa yang literat juga akan berusaha belajar mencari berbagai sumber daya informasi dan cara penggunaan sumber-sumber informasi.

\section{2) Untuk masyarakat}

Literasi informasi bagi masyarakat sangat diperlukan dalam kehidupan seharihari mereka dan dalam lingkungan pekerjaan. Mereka mengidentifikasi informasi yang paling berguna saat membuat keputusan misalnya saat mencari bisnis atau mengelola bisnis dan berbagai informasi dengan orang lain. 
Andi Junudu, Muhammad Rum, Wenny Dastina: Literasi Informasi Petani Nanas

dalam Meningkatkan Produktivitas Pertanian di Desa Tangkit Baru Kec. Sungai Gelam

Kab. Muaro Jambi

\section{3) Untuk pekerja}

Kemampuan dalam menghitung dan membaca belum cukup dalam dunia pekerjaan, karena pada saat ini terjadi ledakan informasi sehingga pekerja harus mampu menyortir dan mengevaluasi informasi yang diperoleh. Bagi seorang pekerja, dengan memiliki kemampuan literasi informasi akan dapat mendukung dalam melaksanakan pekerjaan, memecahkan berbagai masalah terhadap pekerjaan yang dihadapi dan dalam membuat kebijakan.

Manfaat lain dari literasi informasi adalah mendukung kita dalam dunia globalisasi. Untuk dapat bisa bersaing pintar dan kepandaian saja tidak cukup, tetapi yang diutamakan adalah kita harus mampu belajar dengan giat dan berkomunikasi dengan orang lain. Literasi informasi juga dibutuhkan dalam implementasi kurikulum berbasis computer dan menyaratkan peserta didik untuk banyak memanfaatkan sumber informasi dalam berbagai format dan bidang. Dengan demikian ada dua hal yang membuat perlunya literasi informasi, yaitu agar seseorang dapat hidup dan sukses dalam masyarakat informasi, dan secara khusus, dalam penerapan kurikulum berbasis komputer disekolah dan perguruan tinggi.

Berdasarkan beberapa pendapat yang diuraikan diatas maka dapat dikatakan bahwa literasi informasi sangat bermanfaat di era globalisasi yang semakin meningkat dan cepat yang dialami oleh pekerja, pelajar, dan dalam lingkungan masyarakat umum lainnya. Setiap ornag yang memiliki kemampuan literasi informasi maka dapat menciptakan pengetahuan baru dengan menggabungkannya dengan pengetahuan yang sebelumnya ada dan memudahkan dalam pengambilan keputusan ketika menghadapi berbagai masalah maupun ketika membuat suatu kebijakan.

\section{STANDAR LITERASI INFORMASI IFLA}

Literasi informasi mengarahkan pengetahuan dan kesadaran dan kebutuhan seseorang, dan kemampuan untuk mengidentifikasi, menemukan, mengevaluasi, 
Andi Junudu, Muhammad Rum, Wenny Dastina: Literasi Informasi Petani Nanas

dalam Meningkatkan Produktivitas Pertanian di Desa Tangkit Baru Kec. Sungai Gelam

Kab. Muaro Jambi

mengorganisasi dan secara efektif menciptakan, menggunakan, mengkomunikasikan informasi untuk mencari solusi atau masalah yang di dapati, juga merupakan persyaratan untuk berpartisipasi dalam masyarakat informasi, dan merupakan hak asasi manusia untuk belajar sepanjang hayat. Dengan aneka batasan tersebut dan berbagai pengertian tentang literasi informasi maka standar kompetensi bagi literasi informasi juga berada antar Negara.

Menurut Michael Eisenberg bahwa Literasi informasi adalah kemampuan untuk menemukan, mengevaluasi, dan menggunakan informasi dalam berbagai format serta mampu memilih media yang digunakan, juga mencakup pengetahuan, sikap dan etika serta masalah social yang menjadi informasi dan teknologi informasi. (Eisenberg, 2004:6)

Sebagai contoh, berikut ini adalah apa yang disarankan oleh IFLA dalam menguasai literasi informasi, standar Literasi informasi menjadi pembelajaran yang efektif. Standar IFLA mencakup tiga (3) komponen dasar, yaitu akses, evaluasi, dan penggunaan informasi. setiap komponen dibagi menjadi dua (2) sub komponen yang dijeaskan sebagai berikut: (Jesus, 2006:25)

\section{Akses Informasi}

a) Mendefinisikan Kebutuhan Informasi: Menemukan atau menggali kebutuhan informasi; Memutuskan suatu tindakan untuk menemukan informasi; Menyatakan dan menentukan kebutuhan informasi; Mulai melakukan pencarian informasi.

b) Penelusuran Informasi: Mengidentifikasi dan meng-evaluasi sumber-sumber informasi yang potensial: Mengembangkan strategi-strategi pencarian informasi; Mengakses sumber-sumber informasi yang terpilih; Memilih dan menemukan informasi yang dibutuhkan.

\section{Evaluasi Informasi}

a) Penilaian Informasi: Menganalisis, memeriksa, dan menyaring informasi; Menggeneralisasikan dan menginterprestasikan informasi; Memilih dan 
Andi Junudu, Muhammad Rum, Wenny Dastina: Literasi Informasi Petani Nanas

dalam Meningkatkan Produktivitas Pertanian di Desa Tangkit Baru Kec. Sungai Gelam

Kab. Muaro Jambi

menggabungkan informasi; Mengevaluasi keakuratan dan hubungan dari informasi yang ditemukan.

b) Pengaturan Informasi: Menyusun dan mengkategorikan informasi; Menyatukan dan mengatur informasi; Menentukan informasi-informasi yang terbaik dan paling berguna untuk digunakan.

\section{Penggunaan Informasi}

a) Menggunakan Informasi: Menemukan cara untuk mengkomunikasikan, menyajikan dan menggunakan informasi; Mengaplikasikan informasi yang ditemukan; Mempelajari dan mendalami informasi yang ditemukan untuk menjadi pengetahuan pribadi; Mempersentasikan hasil motivasi.

b) Mengkomunikasikan dan menggunakan informasi secara etis: Memahami etika penggunaan informasi; Mematuhi peraturan penggunaan informasi; Mengkomunikasikan hasil pembelajaran dengan pengetahuan intelektual yang dimiliki; Menggunakan pengetahuan yang relevan sesuai dengan standar.

Siti Husaebah Pattah mengungkapkan bahwa Manusia adalah makhluk yang kompleks, banyak manusia membutuhkan sesuatu dalam menjalani kehidupannya. Mulai dari kebutuhan duniawi dan kebutuhan rohani. Fungsi informasi biasa berkembang sesuai dengan bidang garapan yang disentuhnya namun, setidaknya yang utama adalah sebagai data dan fakta yang membuktikan adanya suatu kebenaran sebagai suatu penjelasan yang sebelumnya meragukan dan masih simpang siur dan sebagai prediksi peristiwa-peristiwa yang mungkin akan terjadi pada masa yang akan datang. (Pattah, 2013:16)

\section{METODOLOGI}

Penelitian ini dilakukan di Desa Tangkit Baru Kecamatan Sungai Gelam Kabupaten Muaro Jambi, Provinsi Jambi Tahun 2020.Penelitian ini menggunakan pendekatan kualitatif deskriptif, yang menjelaskan penelitian lapangan yang dilakukan untuk mengetahui gejala yang ada pada saat penelitian. Penelitian ini bertujuan untuk mengetahui pemahaman mengakses, mengevaluasi, serta 
Andi Junudu, Muhammad Rum, Wenny Dastina: Literasi Informasi Petani Nanas

dalam Meningkatkan Produktivitas Pertanian di Desa Tangkit Baru Kec. Sungai Gelam

Kab. Muaro Jambi

menggunakan informasi pada Petani Nanas di Desa Tangkit Baru. Unit populasi adalah seluruh petani nanas di Desa Tangkit Baru. Karena ini bersifat kualitatif maka penulis menggunakan sampel purposif.

Peneliti menetapkan narasumber dalam penelitian ini pada Kelompok Tani yang terdata di Pemerintahan Desa Tangkit Baru.Dalam hal ini masyarakat yang memiliki usaha tani nanas di Desa Tangkit Baru dengan jumlah 16 orang dari 8 kelompok tani yang masing-masing diambil 2 orang untuk di jadikan narasumber.Selanjutnya, dalam penelitian ini penulis mengkategorikan informan yang termasuk ke dalam informan kunci adalah Kepala Desa selaku pimpinan tertinggi pada pemerintahan Desa Tangkit Baru yang diharapkan dapat memberikan informasi-informasi yang tidak dapat di observasi secara langsung. Kemudian adalah ketua kelompok tani yang telah lama berprofesi sebagai Petani Nanas yang diyakini mengetahui pola pertanian nanas dari dulu hingga sekarang, serta mampu memberikan rekomendasi tentang siapa saja yang dapat diwawancara. Selanjutnya adalah informan utama yang terdiri dari masyarakat yang memiliki usaha tani nanas dilingkungan Desa Tangkit Baru. Data dikumpukan melalui metode pengumpulan data Observasi terus terang, wawancara terstruktur dan Dokumentasi. Teknik analisis data yang digunakan adalah skema Flow Model yakni Reduksi Data, Penyajian Data serta Penarikan Kesimpulan. Dengan demikian penelitian yang bersifat deskriptif yang cendrung menggunakan analisis dengan pendekatan induktif, proses dan makna yang ditonjolkan dalam penelitian kualitatif, serta landasan teori yang dimanfaatkan sebagai pemandu agar fokus penelitian sesuai dengan fakta di lapangan, dapat memaksimalkan hasil penelitian yang bermuara pada hal-hal umum.

\section{PEMBAHASAN}

KEMAMPUAN PETANI NANAS DI DESA TANGKIT BARUDALAM MENGAKSES LITERASI INFORMASI

Mengakses informasi membutuhkan ketelitian individu dalam mendefinisikan kebutuhan informasi yang akan dicari dan ditemukannya. Menemukan atau menggali 
Andi Junudu, Muhammad Rum, Wenny Dastina: Literasi Informasi Petani Nanas

dalam Meningkatkan Produktivitas Pertanian di Desa Tangkit Baru Kec. Sungai Gelam

Kab. Muaro Jambi

informasi adalah hal yang penting dilakukan agar tidak terjadi kekeliruan. Selain itu, untuk memulai melakukan pencarian informasi, dibutuhkan alat atau media yang nantinya dapat menunjang kemudahan dalam mencari informasi. Pada era digital saat ini, tidak menutup kemungkinan individu setiap masyarakat dituntut untuk mengikuti trend yang ada. Dimulai dari akses informasi digital melalui jejaringan internet maupun penggunaan teknologi sampai kepada pengaplikasian kehidupan berbasis digital.

Kegiatan pencarian informasi dapat digolongkan pada kebutuhan kognitif seseorang, yaitu kebutuhan akan informasi tentang lingkungannya, tentang fenomena yang terjadi disekelilingnya dan tentang penambahan pengetahuan-pengetahuan baru. (Rum, 2017:10) Maka darinya masyarakat didorong untuk memiliki pemahaman lebih terhadap fenomena perkembangan zaman modern yang serba berkecanggihan ini dengan tujuan agar masyarakat dapat mengakses berbagai informasi sesuai dengan kebutuhan informasinya.

Informasi dapat diperoleh melalui berbagai media, baik media elektronik maupun mediacetak, dari komunikasi verbal/langsung maupun berasal dari komunikasi non verbal/komunikasi tidak langsung yang menggunakan isyarat atau simbol-simbol tertentu. Petani nanas di Desa Tangkit Baru memperoleh informasi dengan asal usul informasi yang cukup variatif, namun sejatinya memiliki kesamaan dalam penelusuran informasi seperti melalui sosialisasi, bertukar fikiran antar sesama petani lainnya, serta melalui keluarga atau secara turun temurun.Selanjutnya, proses memilih dan memilah informasi adalah hal yang tidak terlepas dari penerapan informasi. Penerapan informasi yang telah dipilih dan dipilah dalam hal ini dikaitkan dengan kemampuan petani nanas dalam mengakses informasi akan dapat mempengaruhi hasil produktivitas pertanian itu sendiri. Tentunya tidak terlepas dari kendala-kendala petani dalam memahami sebuah informasi.

Pada era digital saat ini, tidak menutup kemungkinan individu setiap masyarakat dituntut untuk mengikuti trend yang ada. Dimulai dari akses informasi 
Andi Junudu, Muhammad Rum, Wenny Dastina: Literasi Informasi Petani Nanas

dalam Meningkatkan Produktivitas Pertanian di Desa Tangkit Baru Kec. Sungai Gelam

Kab. Muaro Jambi

digital melalui jejaringan internet maupun penggunaan teknologi sampai kepada pengaplikasian kehidupan berbasis digital. Maka darinya masyarakat didorong untuk memiliki pemahaman lebih terhadap fenomena perkembangan zaman modern yang serba berkecanggihan ini dengan tujuan agar masyarakat dapat mengakses berbagai informasi sesuai dengan kebutuhan informasinya.

\section{a. Asal Usul dan cara memperoleh Informasi Bertani Nanas di Desa Tangkit Baru}

Informasi dapat diperoleh melalui berbagai media, baik media elektronik maupun mediacetak, dari komunikasi verbal/langsung maupun berasal dari komunikasi non verbal/komunikasi tidak langsung yang menggunakan isyarat atau simbol-simbol tertentu. Petani nanas di Desa Tangkit Baru memperoleh informasi dengan asal usul informasi yang cukup variatif, namun memiliki kesamana inti dalam penelusuran informasinya. Seperti yang dikatakan Fatajangi Ketua Kelompok Tani "Saweri Gading" sebagai berikut:

"Kalau masalah informasi masalah bertani nanas ini biasanyakan, rata-rata kita dapat sendiri dari pengalaman bekerja mulai dari kecil dari orang tua pengalamannya, jadi kalau cara bertani nanasnya ya lambat laun dapatnya dari situ, kalau pengalamannya ya dari belajar dari pertanian juga ada, dari kelompok-kelompok tani lain berbagi informasi mengenai bagaimana menghasilkan nanas yang berkualitas, cara pemupukannya, cara perawatannya ya biasanya begitu."(Wawancara: Fatajangi 16 Februari 2020)

Hal senada juga dikatakan oleh petani lainnya seperti halnya yang disampaikan oleh Muhammad Idrus Anggota Kelompok Tani “Saweri Gading”. Menurutnya:

"Bertukar pikiranlah sesama petani nanas, soalnya kalau kito nak nyari pengalaman dari luar, orang luarpun belajar dari kito, jadi orang ni cuman memperkuat materi. Jadi kito nikan dilapangan jadi lebih tinggi dari kito. Paling kito nak tau nanas kito nanas kito nikan sejenis nanas queen berukuran sedang, ya jadi yang itu yang kito dapat. Cuman itulah yang kami paham. Soalnya kalau 
Andi Junudu, Muhammad Rum, Wenny Dastina: Literasi Informasi Petani Nanas

dalam Meningkatkan Produktivitas Pertanian di Desa Tangkit Baru Kec. Sungai Gelam

Kab. Muaro Jambi

kito searching di google kan. Ha itulah cuman kito nak tau jenis apa nanas kita ni, soalnyakan jenis nanaskan banyak, ada nanas madu, nanas bogor, kito ni sejenisnya nanas queen.”( Wawancara: Muhammad Idrus 16 Februari 2020)

Menurut pendapat Baso Husni Anggota Kelompok Tani "Siturue":

"Paling dari pengalaman dari kawan masing-masinglah dari sesama petani. Dari kawan-kawan petanilah, kalau dari sosialisasi kebanyakan teori, kalau petani ni maunya langsung praktek yang nyata.”( Wawancara: Baso Husni 10 Februari 2020) Menurut pendapat Amirullah Ketua Kelompok Tani "Berkah Bersama":

"Ya dari segi pengalaman pekerjaan ajah itu dek, pengalaman dari setiap pekerja itukan di hayati dulu diperhatikan hasilnya ini bagaimana pola dari pola cara pupuk.”( Wawancara : Amirullah 16 Februari 2020)

Menurut pendapat Ambo Unang Anggota Kelompok Tani "Berkah Bersama":

"Dari masyarakat sekitar, ya dari petani lainlah yang lebih berpengalaman kalau kitakan istilahnya masih baru, masalah-masalah supaya cepat subur macam mano caranyakan itu didapat dari yang lebih berpengalamanlah kayak petanipetani lamokan."( Wawancara : Ambo Unang 16 Februari 2020)

Menurut Yoyong Maris Ketua Kelompok Tani “Mappakengka” sedikit berbeda dari petani lainnya yakni informasi didapatkan dari pembinaan pertanian namun tidak terlepas dari komunikasi sesama petani:

"Selamo inikan kitokan apo, sedikitkan ada pembinaan dari pertanian terus iyo paling idakkan anggotakan diundang ikuti rapat di desa"( Wawancara :Yoyong Maris 16 Februari 2020)

Ada juga informasi-informasi yang ditemukan asalnya dari turun temurun, atau dalam hal ini dari kakek maupun bapak. Beberapa informan ini penulis temui di lapangan dengan mengungkapkan hal serupa seperti yang disampaikan pada saat wawancara sebagai berikut:

Menurut pendapat Andi Hamzah Ketua Kelompok Tani "Siturue": 
Andi Junudu, Muhammad Rum, Wenny Dastina: Literasi Informasi Petani Nanas

dalam Meningkatkan Produktivitas Pertanian di Desa Tangkit Baru Kec. Sungai Gelam

Kab. Muaro Jambi

"Kitakan dapat secara turun temurunkan, bukan dapat dari internet, disinikan turun temurun. Dari pengalaman sesama anggota bisakan, hem saling sharinglah sama-sama anggota satu kelompok tani, misalnyakan penggunaan pupuknya gimana?, dari pengalaman tulah, kalau dari informasi secara global tu, kurang anulah kita" (Wawancara :Andi Hamzah 10 Februari 2020)

Menurut ungkapan Andi Uswat Rasik Ketua Kelompok Tani "Karre":

"Kalau informasi tu kan selama ini kan iya turun temurun, tapi ya sebagian dari kawan-kawan.”( Wawancara: Andi Uswat Rasik 1 Maret 2020)

Juga senada dengan pendapat Bunga Rosi Ketua Kelompok Tani "Subur 4":

"Kalau pertama nanam nanasnyakan dari pak datuk giming, dari bapak kita dulu nah itulah yang kita lanjutkan sampai sekarang. Nanas inikan sekali tanam nah itulah yang kita teruskan sampai sekarang, jadi informasinya itu dari bapak kitalah dak, soalnya kita cuman meneruskan. Dari PKK kan ada pertemuan kadang juga." ( Wawancara : Bunga Rosi 16 Februari 2020)

Menurut Muftar Anggota Kelompok “KWT Sumber Jaya” mengatakan bahwa:

"Kalau misalnya informasi tu dari paman sama keluarga sih dari kawan-kawan kurang, palingan dari keluarga saudara sih.”( Wawancara : Mufta 1 Maret 2020)

Berdasarkan wawancara diatas setelah dilakukan analisis, menunjukkan bahwa dari beberapa informan rata-rata mengatakan informasi yang berkenaan dengan asal usul serta cara mendapatkannya sama-sama melalui sosialisasi atau bertukar fikiran sesama petani lainnya serta ada juga informasi yang didapatkan melalui keluarga dalam hal ini secara turun temurun.

\section{b. Penerapan Informasi serta Kendala Pemahaman Petani dalam Bertani Nanas di Desa Tangkit Baru}

Proses memilih dan memilah informasi adalah hal yang tidak terlepas dari penerapan informasi. Penerapan informasi yang telah dipilah dan dipilah dalam hal ini dikaitkan dengan kemampuan petani nanas dalam mengakses informasi akan dapat mempengaruhi hasil produktivitas pertanian itu sendiri. Tentunya tidak terlepas dari kendala-kendala petani dalam memahami sebuah informasi. Seperti yang 
Andi Junudu, Muhammad Rum, Wenny Dastina: Literasi Informasi Petani Nanas

dalam Meningkatkan Produktivitas Pertanian di Desa Tangkit Baru Kec. Sungai Gelam

Kab. Muaro Jambi

dikatakan oleh Andi Hamzah Ketua Kelompok Tani Siturue dalam wawancara sebagai berikut:

"Ee, paling-paling kita istilahnya ya kita ikutilah mana yang terbaik kan, istilahnya pertiga bulan kita coba gimana pengalamannya ini kawan satukan dan satu lagi gimana, jadi kita ambil yang terbaik mana. Kalau, kendalanya, kitakan masalah kendalanya tukan, kalau nanaskan belum termasuk, atau paling kendalanya tukan kalau pupuk langkah, peptisidanya langkah, ha itulah. Kemudian yang lebih parahnya lagikan masalah pemasarannya gitukan.”( Wawancara : Andi Hamzah 10 Februari 2020)

Senada dengan pendapat Muhammad Idrus Anggota Kelompok Tani Saweri Gading:

"Kito liat jugo dari pengalaman kawan yang sudah berpengalaman jadi disitulah kito saling bertanya kan, jadi kalau misalkan ini cara bertaninyo pengalaman jadi kito disitulah kita bertukar pikiran. Kalau kendala paling hama, kayak tikus, atau pada pemupukan"( Wawancara : Muhammad Idrus 16 Februari 2020)

Menurut Bunga Rosi Ketua Kelompok Tani "Subur 4" menyatakan bahwa:

"Kalau sekarangkan kita sudah jadi luas sedikitlah, sudah ketemulah namanya pertanian (Penyuluh) dari situlah ilmunya kemudian kita terapkan di kebun kita dari informasi gapoktan disitu kita bentuk kelompok tani, ha dari situlah dapat pupuknya juga yang murah. Dulukan yang dak dipaham tu kalo misalnya mau pupuknya itukan yang mana aja yang dicampur kalo ureanya berapa kalo KCLnya berapa dulukan mahal nian dak bisa kita beli karena nanas murah betul.”( Wawancara : Bunga Rosi 16 Februari 2020)

Menurut Baso Husni Anggota Kelompok Tani "Siturue" mengugkapkan bahwa:

"Betahaplah, dak langsung yang mana sesuai dengan cuaca kan racun, racunkan waktunya yang pas kan kemarau atau musim inilah tidak terlalu banyak curah 
Andi Junudu, Muhammad Rum, Wenny Dastina: Literasi Informasi Petani Nanas

dalam Meningkatkan Produktivitas Pertanian di Desa Tangkit Baru Kec. Sungai Gelam

Kab. Muaro Jambi

hujan. Kalau anjuran pemerintah, nanas itu diusahakan menghindari ini pupuk kimia, menghindari kayak misalkan sefa, yang berhubungan dengan kimialah.”( Wawancara : Baso Husni 10 Februari 2020)

Menurut Muftar anggota Kelompok Tani "KWT Sumber Jaya":

"Cara aku sih kalau nak anu informasi tu harus turun kelapangan juga. Kendalanya Ada, nerbas susahnya disitu waktu dulu, kalau sekarang bisalah semenjak tau mudahlah.”( Wawancara : Muftar 1 Maret 2020)

Menurut Abdul Hamid Anggota Kelompok Tani "Mappakengka":

"Dari abdul rahim, ikut belajar-belajar, namun kubilang dak hidup aku kalau gini caranya. Cara kerjanya susah, duri semua, tapi setelah tau justru enak di nanas daripada di kelapa. Simpel kalau nanas itu sistemnya dak dipaksa kalau kelapa dipaksa dari segi pementikannya. Kendalanya Ada itu batang itu walaupun kita sefa bahkan tiga kali dak mau juga berbuah ha itulah dak tau masalahnya."( Wawancara : Abdul Hamid 1 Maret 2020)

Menurut Ambo Sau Anggota Kelompok Tani “Mandiri” mengungkapkan:

"Ya namanya petani sesama petanilah, cuman berbagi sama BPTP jugalah. Ya kalau cara-caranya langsunglah, kayak jarak-jarak tanam $50 \mathrm{~cm}$ juga banyak yang lain."( Wawancara : Ambo Sau 1 Maret 2020)

Pendapat diatas sedikit berbeda dari pendapat beberapa informan berikut sperti halnya Fatajangi Ketua Kelompok Tani “Saweri Gading” menyatakan:

"Biasanya kalau untuk menerapkan itu, kami istilahnya kalau ada informasi kami kumpulkan anggota, kami berbagi informasi bahwa kalau untuk mendapatkan nanas yang berkualitas seperti ini, jadi kami rembuk misalnya rapat atau dalam pertemuan kelompok tani ya disitulah kami bisa berbagi pengalaman bahwa, oh nanas yang begini butuh begini. Kalau kendalanya sih mungkin kalau dari cara bertaninya mungkin gak ada, gak begitu signifikanlah kalau masalah kendala, Cuman kalau biasanya sih kalau masalah kendala tidak 
Andi Junudu, Muhammad Rum, Wenny Dastina: Literasi Informasi Petani Nanas

dalam Meningkatkan Produktivitas Pertanian di Desa Tangkit Baru Kec. Sungai Gelam

Kab. Muaro Jambi

dengan cara bertaninya, Cuman biasanya di pemasaran yang ada kendala."( Wawancara : Fatajangi 16 Februari 2020)

Menurut Amirullah Ketua Kelompok Tani "Berkah Bersama":

"Dari inilah dari setidak-tidaknya kita buat contohnya seperti ini kalau misalnya cocok dari orang yang kita kasih tau ikuti, kalau dak sudah. Kalau kendalanya Kalau untuk sekarng sih alhamdulillah lah.”( Wawancara : Amirullah 16 Februari 2020)

Menurut Ambo Unang Anggota Kelompok Tani "Berkah Bersama”:

"Mempraktekkan langsung ke kebun-kebun. Kendalanya itu pemasarannya kadang harganyo, dari segi harga juga mencari informasi supaya kebun tu subur terus.”( Wawancara : Ambo Unang 16 Februari 2020)

Menurut Nurzaedah Ketua Kelompok Tani "KWT Sumber Jaya”:

"Ya kita sosialisasi lah ke kawan-kawan tu, soal bisa gak kita jalanin kemarin yang dari dinas apa itu, ada dinas yang bantu bikin pupuk dari olahan limbah sapi itu atau kotoran sapi dia nyoba di parit 6 SD tu kemarin bagus katanya berhasil. Kendalanya kalo aku gak tau, soalnya yang tau bertani nanas sepenuhnya itu bapaknya, memang dak tau bertani nanas.”( Wawancara : Andi Nurzaedah $1 \mathrm{M}$ aret 2020)

Berdasarkan hasil wawancara dari beberapa informan di atas menyatakan bahwa petani Nanas di Desa Tangkit Baru dalam mengakes literasi informasi umumnya melalui sosialisasi dari teman-teman atau sesama petani lainnya, dengan memilih dan memilah informasinya terlebih dahulu kemudian diterapkan sedikit demi sedikit sebelum penerapan pada skala yang besar. Namun rata-rata petani menerapkan informai yang didapatkan secara langsung. Adapun kendala yang dialami tidak cukup jelas karena faktanya tidak semua petani bisa menggunakan atau mengakses informasi dengan memanfaatkan media yang ada. Media yang dimaksukan adalah 
Andi Junudu, Muhammad Rum, Wenny Dastina: Literasi Informasi Petani Nanas

dalam Meningkatkan Produktivitas Pertanian di Desa Tangkit Baru Kec. Sungai Gelam

Kab. Muaro Jambi

seperti media telepon pintar yang berbasis internet. Kekurangan inilah yang membuat petani nanas di Desa Tangkit Baru berada pada keterpaksaan untuk mengkaji sebuah informasi melalui praktik langsung dilapangan.Sehingga para petani yang pendidikannya rata-rata hanya di tingkat SMP/SLTP mampu memunculkan produktifitas pertaniannya pada permukaan sektor buah tropis (nanas) di provinsi jambi.

\section{KEMAMPUAN PETANI NANAS DI DESA TANGKIT BARU DALAM MENGEVALUASI LITERASI INFORMASI}

Proses penilaian serta pengaturan informasi adalah sebuah evaluasi informasi. Penilaian informasi dibutuhkan keterampilan menganalisis, memeriksa, dan menyaring informasi. Kemampuan ini digunakan agar masyarakat dapat memilah dan memilih informasi yang paling memiliki nilai guna untuk diterapkan. Biasanya informasi yang diperoleh dengan tidak di evaluasi sebelumnya akan berdampak negatif pada penerapannya. Namun sebaliknya, jika informasi yang diperoleh tidak di telan mentah-mentah dan sebelumnya dinilai terlebih dahulu pastinya akan berdampak positif.

Hambatan dalam meraup informasi yang baik seringkali kita temukan dalam penelusuran, namun tidak menutup kemungkinan kita tetap mencarinya karena informasi yang kita cari dirasakan penting untuk menunjang pekerjaan secara cepat dan tepat.Membandingkan infomasi kemudian dievaluasi adalah hal yang sangat penting untuk dilakukan agar penerapan informasi nantinya sesuai dengan harapan awal. Secara optimal penerapan informasi bisa dilakukan apabila petani mampu membandingkan informasi yang terbaik serta mengevaluasi informasi sebelum digunakan.

\section{a. Jenis Tanaman Nanas di Desa Tangkit Baru dan Pemahaman Petani terhadap Manfaat Buah Nanas yang di tanamnya}

Berbagai jenis tanaman nanas di kawasan hujan tropis seperti di indonesia cocok untuk di budidaya pada lahan yang tersedia, jenis tanaman nanas itu meliputi: 
Andi Junudu, Muhammad Rum, Wenny Dastina: Literasi Informasi Petani Nanas

dalam Meningkatkan Produktivitas Pertanian di Desa Tangkit Baru Kec. Sungai Gelam

Kab. Muaro Jambi

Jenis nanas queen, nanas madu dll. Tentunya tanaman nanas tersebut memiliki manfaat bagi kesehatan, peningkatan perekonomian maupun lainnya. Sebagaimana yang diungkapkan Fatajangi Ketua Kelompok Tani "Saweri Gading”:

"Jenisnya, kalau jenisnya yang paling utama di kami tulah, nanas queen jenis muris namanya. Oh kalau manfaatnya buah nanas itu banyak, seperti untuk paru-paru biasanya untuk kesehatan perokok itu paling bagus itu makan nanas. Kemudian vitamin nya, vitamin $\mathrm{C}$ nya sangat tinggi. Kalau pun untuk pengolahannya juga banyak, mau dibikin selai, mau di bikin rujak pun bisa juga, mau bikin dodol juga bisa, mau di bikin kue juga bisa. kalau hasilnya sangat membantulah, masalahnyakan itu termasuk komoditi utama di tangkit baru. Karena kalau, tanaman lain di tangkit baru itu tidak bisa.”( Wawancara : Fatajangi 16 Februari 2020)

Senada dengan petani lainnya seperti Baso Husni anggota Kelompok Tani "Siturue":

"Jenisnya ada dua dulu bogor sama queen. sekarang umum queen. Yah salah satunya, untuk obati kolestrol. Lumayanlah, tergantung orangnya. Potensi lebih besar jika perawatan baik.”( Wawancara: Baso Husni 10 Februari 2020) Menurut Andi Hamzah Ketua Kelompok Tani "Siturue" megatakan bahwa: "Jenis nanas queen, varietas queen dak salah. Dan kita punya satu kumpulan kelompok tanikan dinamakan nanas queen (jenisnya). Ya kalau masalah kesehatankan pernah juga dengar dari media tv lah yakan, ha katanya nanas itu untuk kolestrol, kemudian yang apanya yang batang dalam itu Iso fandreng, ha itu katanya bisa mencegah kanker katanya."( Wawancara: Andi Hamzah 10 Februari 2020)

Menurut Yoyong Maris Ketua Kelompok Tani “Mappakengka” megatakan bahwa: 
Andi Junudu, Muhammad Rum, Wenny Dastina: Literasi Informasi Petani Nanas

dalam Meningkatkan Produktivitas Pertanian di Desa Tangkit Baru Kec. Sungai Gelam

Kab. Muaro Jambi

"Masyarakat kita disinikan nanas quenn dak dipakek. Manfaatnya Salah satunyakan untuk membuang kolestrol, untuk meningkatkan stamina apalagi vitamin $\mathrm{C}$ nyakan sangat bagus sekali untuk tubuh.”( Wawancara: Yoyong Maris 16 Februari 2020)

Menurut Andi Nurzaedah Ketua Kelompok Tani "KWT Sumber Jaya" menyatakan hal yang sama bahwa:

"Nanas queen atau ratu, nanas queen kata fuang (kepala desa) nanas queen yang banyak kita kembangkan sekarang tu nanas queen rata-rata. Yang nanas madu tu satu-satu karena nanas madu tukan sekali tanam, kalau nanas queen tu di tanam sekali anaknya banyak kalau itu dak bisa. Manfaatnya ya lumayan baguslah soalnya sudah menambah penghasilan buah nanas itukan bisa jadi obat juga yadak, yang anu tu penurun kolestrol, banyak manfaatnya yang itu.”( Wawancara : Andi Nurzaedah 1 Maret 2020)

Menurut Andi Uswat Rasik Ketua Kelompok Tani "Karre"” menyatakan bahwa:

"Ha inilah kalau masalah jenis itu, kadang lain daerah lain jenis. Kalau yang kita disini katanya sih nanas moris hampir samalah dengan nanas queen. Manfaatnya buah nanas sih ya sebagian untuk dimakan, bikin kue, katanya sih kandungan vitamin C tinggi.” (Wawancara: Andi Uswat Rasik 1 Maret 2020)

Informan yang berjumlah 16 orang rata-rata mengutarakan bahwa jenis tanaman nanas yang ditanam di Desa Tangkit Baru adalah jenis nanas queen yang memiliki manfaat sebagai pengatur kolestrol, memiliki kandungan vitamin $\mathrm{C}$, dapat membersihkan paru-paru juga dapat di olah untuk dijadikan usaha tambahan seperti pembuatan kue, keripik, dan selai.

\section{b. Pemahaman Bertani Nanas dengan Efeketif dan Efisien yang dapat mempengaruhi Hasil Tanaman Nanas di Tangkit Baru}

Selain indikator di atas, efektifitas dan efisiensi juga menjadi tolak ukur dalam pengevaluasian informasi. Tentunya juga berpengaruh terhadap faktor-faktor yang dapat mempengaruhi seorang petani tidak memahami cara bertani nanas dengan baik. 
Andi Junudu, Muhammad Rum, Wenny Dastina: Literasi Informasi Petani Nanas

dalam Meningkatkan Produktivitas Pertanian di Desa Tangkit Baru Kec. Sungai Gelam

Kab. Muaro Jambi

Seperti yang dikatakan Andi Hamzah Ketua Kelompok Tani "Siturue" sebagai berikut:

"Sebenarnyakan kitakan pemahamannya ya alhamdulillah lah dari pengalaman, dari kerja sama dari satu kelompok, sharing pendapat, alhamdulillah lumayanlah.Kalau hasilnya termasuk lumayanlah, kan masyarakat nikan sudah bisa mengatur, mengatur apa hasil produksi tukan bisa di atur, kapan bisa diatur tuk mancing buah keluar sudah bisa, kemudian termasuk baguslah, cuman itulah kendalanya pemasarannya dak, kalau untuk produksinya udah lumayanlah”( Wawancara: Andi Hamzah 10 Februari 2020)

Fatajangi Ketua Kelompok Tani "Saweri Gading” mengungkapkan hal yang berbeda:

"Kalau efektif dan efisien tu, kalau zaman dulu tu emang masih sangat tradisional masalah untuk bertaninya. Dulu, masih makai sepeda, pakai ambung. Kalau sekarang sih, sudah sangat efektif karena pengangkutan nanasnya sudah memakai gerobak, kemudian untuk mengeluarkannya pun sudah memakai motor, dan kemudian untuk pemupukan kan dulu istilahnya cuman pakai dihambur pakai tangan, ini sekarang sudah bisa pakai mesin, untuk penyemprotan nya pun dulu makai semprot yang tangan, sekarang sudah pakai mesin. Jadi, kalau efektif sudah sangat efektif sekarang untuk masalah petanian ini. Kalau tepat penggunaannya bisa dalam pemupukannya bisa dalam 2 kali setahun dan juga bisa dalam 3 kali dalam setahun tapi karena ada yang dikejar seperti bulan ramadhan maka agak di banyakkan pemupukannya supaya target terpenuhi karena pembeli banyak di bulan ramadhan.( Wawancara: Fatajangi 16 Februari 2020)

Baso Husni Anggota Kelompok Tani "Siturue" mengungkapkan:

"Tau, cuman kadang dak sesuai dengan bajajnya, pernah dapat bantuan tapi jarang dan tidak tepat sasaran.’( Wawancara: Baso Husni 10 Februari 2020) 
Andi Junudu, Muhammad Rum, Wenny Dastina: Literasi Informasi Petani Nanas

dalam Meningkatkan Produktivitas Pertanian di Desa Tangkit Baru Kec. Sungai Gelam

Kab. Muaro Jambi

Muhammad Idrus Anggota Kelompok Tani "Saweri Gading" mengungkapkan:

"Kalau masalah efisiennya itu, kito biso mengatur kapan kito nak panen nanas itu, kalau kato orang sinikan sefa, jadi itu membutuhkan waktu empat bulan setengah ha itu yang buat kito efisien jadi kito biso tau kapan misalnya kito mau bulan puaso. Empat bulan setengah sebelum itu kito mulai sefa. Kalau misalkan tanaman lain dak bisa diatur. Kalau penghasilan, sekarang nikan kalo di tangkit nikan mayoritas petani nanas jadi itukan yang sangat ketergantungan di kebun nanas, jadi kalau misalnya kebutuhan sehari-hari dari hasil kebun nanas sendiri. Karena kebanyakan penghasilan dari kebun nanas sangat menjanjikan.”( Wawancara: Muammad Idrus 16 Februari 2020)

Amirullah Ketua Kelompok Tani "Berkah Bersama” mengungkapkan: "Yang umumnya, pahamlah macam itulah, iya karena dari dulu sampai sekarang gak ada yang berubah, yang berubahkan cuman sistem sefanya dipercepat.Kalau hasilnya ya termasuk golongan standarlah, dak di bawah nian dak di atas nian.”( Wawancara: Amirullah 16 Februari 2020)

Ambo Unang Anggota Kelompok Tani “Berkah Bersama” mengungkapkan: "Ya itu kalau buah nanas ni harus di anu dipupuk terus, kalau dak dipupuk ya buahnya ya kurang banyak kurang besar. Kalau dari awal penanaman nanas sampai ke berbuah ya, kalau kita mulai nanam tu dari awal kurang lebih satu tahun sudah bisa di ambil buahnya. Kalo untuk khususnya ditangkit baru ni mayoritas pendapatan masyarakat sinikan itulah $70 \%$ dari petani nanas ya sangat bagus untuk perekonomian disini kebanyakan masyarakat desa disini tergantung dari buah nanas.”( Wawancara: Ambo Unang 16 Februari 2020) Yoyong Maris Ketua Kelompok Tani “Mappakengka” mengungkapkan: "Sekarang inikan apalah yang gak bisa, jadi ada sistem sefalah sekarang nikan jadi emang orang tangkit ini sekian bulan nanasnya bisa kita ambil semua. 
Andi Junudu, Muhammad Rum, Wenny Dastina: Literasi Informasi Petani Nanas

dalam Meningkatkan Produktivitas Pertanian di Desa Tangkit Baru Kec. Sungai Gelam

Kab. Muaro Jambi

Kalau hasil untuk sekarang ini lumayanlah semakin meningkat lah."( Wawancara: Yoyong Maris 16 Februari 2020)

Andi Nurzaedah Ketua Kelompok Tani "KWT Sumber Jaya" mengungkapkan:

"Mungkinlah bisa, yakan orang punya sistem kerja masing-masing jadi ya muski makai cara dia masing-masing karena lain-lain cara orang. Kalau saya bagus, karena rata-rata ditangkit ini petani nanas sukses yang saya lihat, yang bertani nanas itu lumayanlah penghidupannya."(Wawancara: Andi Nurzaedah 1 Maret 2020)

Begitu pula yang di ungkapkan oleh Muftar Anggota Kelompok Tani "KWT Sumber Jaya" mengungkapkan:

"Kalau dari efektif itu cara nanam nanas yang benar tu kalau rajin bersihin ke kebun bisa mengolah dengan baik pastinya hasilnya akan maksimal mungkin. Sangat baiklah kalau dari tangkit baru ni, pokoknya dak ada yang bisa tandingilah tangkit baru ni khususnya dijambi."(Wawancara: Muftar 1 Maret 2020)

Hasil wawancara diatas dari 16 informan yang mewakili para petani nanas di Desa Tangkit Baru menerangkan bahwa penerapan bertani nanas secara efektif dan efisien yang dapat mempengaruhi hasil tanamnya telah dilakukan dan terus dikembangkan. Ini terlihat dari para petani yang telah menerapkan cara-cara yang cepat dalam berbudidaya seperti penggunaan pupuk yang variatif, penggunaan sefa (zat penumbuh kembang nanas), serta melakukan perawatan berkelanjutan. Namun perlu adanya optimalisasi edukasi tambahan yang berasal dari penyuluh-penyuluh pertanian agar hasil tanaman nanas dapat dikategorikan steril dari penggunaan pupuk kimia yang kerap digunakan. Selain itu, dibutuhkan pula seseorang yang mampu memberikan inovasi baru terhadap pembersihan lahan dengan efektif tanpa sentuhan zat atau bahan kimia. Sehingga mampu memberikan dampak yang baik bagi 
Andi Junudu, Muhammad Rum, Wenny Dastina: Literasi Informasi Petani Nanas

dalam Meningkatkan Produktivitas Pertanian di Desa Tangkit Baru Kec. Sungai Gelam

Kab. Muaro Jambi

kesehatan yang mengkonsumsinya bilamana petani tidak menggunakan pupuk kimia atau peptisida.

Membandingan informasi menurut petani nanas di Desa Tangkit Baru ratarata dilakukan dengan cara yang berbeda-beda seperti, praktik langsung dilapangan dengan perbandingan hasil tanam, perawatannya yang baik, kemudian ada pula yang menyaring informasi yang terbaik terlebih dahulu kemudian diterapkan. Namun kesemuanya memiliki kesamaan tujuan yakni meraup hasil yang terbaik dan menggunakan waktu yang ringkas. Hal inilah yang membuat para praktisi petani nanas di Desa Tangkit Baru secara terus menerus terdorong untuk melakukan sebuah evaluasi informasi.

\section{KEMAMPUAN PETANI NANAS DI DESA TANGKIT BARU DALAM MENGGUNAKAN LITERASI INFORMASI \\ a. Penerapan Informasi yang bermanfaat bagi Petani}

Informasi yang telah ditemukan kemudian di pilah yang seterusnya dievaluasi sebelum di terapkan adalah informasi yang tentunya memiliki manfaat. Penerapan informasi yang dilakukan petani nanas di Desa Tangkit Baru ada yang secara langsung dan ada pula yang melalui penyeleksian terlebih dahulu. Sebagaimana yang diungkapkan Fatajangi Ketua Kelompok Tani "Saweri Gading”:

"Biasanya sih kalo misalnya ada informasi dari kawan atau rekan-rekan petani lain, biasanya sih kita, pertama membandingkan dulu hasil buahnya bagaimana. Paling kalau misalnya memang bagus, kami coba-coba menerapkan, misalnya bagus baru kita menerapkan. Kalau informasi sih sangat bermanfaat kalau dari rekan-rekan, karena istilahnyakan untuk kepentingan kita bersama juga ya informasinya."(Wawancara: Fatajangi 16 Februari 2020)

Hal senada yang diungkapkan oleh Muhammad Idrus Anggota Kelompok Tani "Saweri Gading": 
Andi Junudu, Muhammad Rum, Wenny Dastina: Literasi Informasi Petani Nanas

dalam Meningkatkan Produktivitas Pertanian di Desa Tangkit Baru Kec. Sungai Gelam

Kab. Muaro Jambi

"Ha itu saya langsung nerapkan, langsung terjun kelapangan. Kalau itu bermanfaat, jelas bermanfaat untuk kebutuhan sehari-hari, untuk tabungan juga ada"( Wawancara: Muhammad Idrus 16 Februari 2020)

Muftar Anggota Kelompok Tani "KWT Sumber Jaya” mengungkapkan:

"Kalau dapat informasi tu ya langsung kita terapkan karena usaha tu harus berkorban gitunah, kalau orang susah tu harus berkorban dulu dari awal. Kalau saya sangat bermanfaat, apalagi kalau orang pemula sangat bermanfaat. Yang penting tu kalau pertama jangan ragu-ragu terjun ke lapangan."'( Wawancara: Muftar 1 Maret 2020)

Abdul Hamid Anggota Kelompok Tani "Mappakengka" mengungkapkan: "Iya emang langsung kita terapkan informasi yang kita dapat tapi juga pilihlah mana yang baik untuk diterapkan. Informasi iya betul bermanfaat informasi tu."( Wawancara: Abdul Hamid 1 Maret 2020)

Bunga Rosi Ketua Kelompok Tani “Subur 4" mengungkapkan bahwa:

"Iya langsung, langsung dicobalah diuji cobalah soalnya segitu pengennya mencoba kan apa yang dibilangin langsunglah di uji coba, berhasil atau tidaknya urusan nanti. Alhamdulillah ada yang bermanfaatlah kayak punya (nama disamarkan) sangat bermanfaat nian cuman kita perlahan-lahan soalnyakan masing-masing disini luas kebunnya dak sama orang di luar cuma mungkin seperempat hektar, kalau disinikan sampai 2-4 hektar."

Wawancara: Bunga Rosi 16 Februari 2020)

Yoyong Maris Ketua Kelompok Tani "Mappakengka" mengungkapkan bahwa:

"Iyalah kita cobalah dulu kadang petani inikan seperti itu, kadang merekakan mau tau informasikan apa yang bagus, pupuk apa yang bagus, racun apa yang bagus ya kadang naanya informasi ya seperti itulah kita cobak dulu. Ya kalau informasi itukan ya sangat bermanfaat lah, tapi ya kita kembali ke faktor cuaca lagi tu.”( Wawancara: Yoyong Maris 16 Februari 2020) 
Andi Junudu, Muhammad Rum, Wenny Dastina: Literasi Informasi Petani Nanas

dalam Meningkatkan Produktivitas Pertanian di Desa Tangkit Baru Kec. Sungai Gelam

Kab. Muaro Jambi

Begitu pula yang diungkapkan oleh Ambo Unang Anggota Kelompok Tani "Berkah Bersama":

"Iya langsung diterapkan informasinya. Informasi pasti bermanfaat, itu yang tadi bermanfaat untuk pertamo untuk menambah pengetahuan cara bertani nanas kedua untuk menambah produktivitas tanaman."(Wawancara: Ambo Unang 16 Februari 2020)

Amirullah Ketua Kelompok Tani "Berkah Bersama" mengungkapkan:

"Kalo aku dari sekelompok ini langsung diterapkan, coba apa masalahnya dicoba kalo sekiranya bagus masuk hitungannya silahkan.Banyak juga bermanfaat salah satunya informasi sefa awalnyakan dari kawan ngasih tau cobalah tes, itu sangat bermanfaat."'(Wawancara: Amirullah 16 Februari 2020)

Setelah mewawancarai satu persatu informan diatas, ditemukan bahwa sebenarnya informasi yang didapatkan langsung diterapkan dengan percobaan terlebih dahulu, tidak sedikit dari informan diatas mengatakan bahwa penerapan informasi yang didapatkan seperti penggunaan pupuk kimia (sefa), langsung diterapkan dengan alasan agar pertumbuhan nanas lebih cepat walau tidak seefesien yang diharapkan. Disinilah telah dilakukan analisis dan ditemukan bahwa petani yang mengalami peningkatan dengan hasil produksi kurang optimal, dikarenakan adanya ambisi untuk menghasilkan buah yang banyak, sehingga memberikan hasil yang banyak pula. Namun, tidak memikirkan dampaknya bagi kesehatan apabila menggunakan unsur/bahan kimiawi. Walau begitu, berdasarkan wawancara dari 16 informan diatas menunjukkan bahwa kesadaran para petani akan manfaatnya informasi rata-rata menyatakan diri.

\section{b. Menyebarkan dan Mengkomunikasikan Informasi}

Persoalan mengkomunikasikan informasi terletak pada kepribadian petani itu sendiri, mampukah petani untuk bersosialisasi dengan sesama petani lainnya atau malah sebaliknya. Pemahaman akan pentingnya menyebarkan dan mengkomunikasikan informasi dengan baik, sangatlah dibutuhkan karena dapat 
Andi Junudu, Muhammad Rum, Wenny Dastina: Literasi Informasi Petani Nanas

dalam Meningkatkan Produktivitas Pertanian di Desa Tangkit Baru Kec. Sungai Gelam

Kab. Muaro Jambi

memberikan manfaat sesama petani demi kesejahteraan bersama. Seperti yang diungkapkan oleh Fatajangi Ketua Kelompok Tani Saweri Gading sebagai berikut:

"Kalau misalnya kami bertani ya rata-rata kami bagi-bagilah, misalnya ini pemupukan bulan ini, begini yang bagus, misal penghujan yang begitu. Karena misalnya pemupukan dikemarau kan gak bisa, jadi tetap rata-rata misalnya ni bulan ini, ini tembakan untuk bulan puasa jadi pemupukannya begini Kalau komunikasikannya, kalau sesama petani ya begitu ajah kalau misalkan ketemu pertemuan itu kita informasikan. Kalau sesama rekan-rekan petani yang lain biasanya orang tu bertanya sendiri begitu. Gimana sih kok bisa nanasnya begini, jadi kami bagi oh begini ini di inikan pemupukannya begini."( Wawancara: Fatajangi 16 Februari 2020)

Pendapat yang sama dengan Andi Hamzah Ketua Kelompok Tani "Siturue": "Ya Alhamdulillah, disebarkan. Jangan istilahnya ada pengalaman penggunaan peptisida misalnyakan ha sudah ketemu misalnya racun ini, saya makai ini hancur semua nanas saya, kita kasih tau ke orang bagus kan salah. Istilahnya kita sharinglah misalnya racun yang bagus yang mana, peptisida yang mana yang untuk nanas kan tidak semuanya peptisida tukan bagus. Kadang-kadang ya saling gotong royongkan bisa, waktu rapat-rapat kelompok tani bisa, ketemu dijalanpun kan bisa, gak meski ada ketentuannya gitukan"( Wawancara: Andi Hamzah 10 Februari 2020)

Muhammad Idrus Anggota Kelompok Tani "Saweri Gading" mengungkapkan:

"Ya saya sebarkan sesama kelompok tani saya, ke orang juga kalo misalnyo kalo saling memberi informasi ya kami salurkan. Itu dengan kalo sama kelompok tani paling kalo pada saat rapat, disitulah kita saling memberi informasi pengalaman apa yang ada dengan kawan ha itulah yang memberi informasi disitulah saling memberi informasi pada saat rapat tersebut."( Wawancara: Muhammad Idrus 16 Februari 2020) 
Andi Junudu, Muhammad Rum, Wenny Dastina: Literasi Informasi Petani Nanas

dalam Meningkatkan Produktivitas Pertanian di Desa Tangkit Baru Kec. Sungai Gelam

Kab. Muaro Jambi

Ambo Sau Anggota Kelompok Tani “Mandiri” mengungkapkan:

"Ku sebarkan kekawan-kawan yang lain kalau ketemu. Ya kalau ketemu di jalan, duduk-duduk kukasih taulah informasinya cara-caranya." (Wawancara: Ambo Sau 1 Maret 2020)

Abdul Hamid Anggota Kelompok Tani "Mappakengka" mengungkapkan:

"Kalau itu kalau ada yang nanya saya kasih tau, cuman kalau ndak yo ndaklah paling kalau kita lagi ngumpul-ngumpul eh kok bisa besar nanasnya, nah disitulah nanti kita bicarakan.”( Wawancara: Abdul Hamid 1 Maret 2020)

Andi Nurzaedah Ketua Kelompok Tani "KWT Sumber Jaya" mengungkapkan:

"Ya karena kita ada kelompok ya kita sosialisasikan dalam kelompok itu kita saling kabar-kabari. Kita bikin pertemuan kalau dak tu kita bahas digroup kan ada sekarangkan zaman teknologi jadi kita bikin group disitulah membahasnya tanpa pertemuan secara khusus disitulah dibahas."

Begitu pula Muftar Anggota Kelompok Tani "KWT Sumber Jaya" mengungkapkan:

"Kalau misalnya itu sih adalah kawan-kawan nanya tapi aku bilanglah ini tergantung dari tingkar kadar airnya tempat kita masing-masing walaupun misalkan batang nanas itu besar ditempat yang lain tapi belum tentu buanya bagus rasanya berbeda. Ya simpel, Cuma bilang ajah tanam kayak gini pertumbuhannya akan setahun baru ada buahnya. Palingan itu cuman dirumah, dirumah kawan."( Wawancara: Muftar 1 Maret 2020)

Bunga Rosi Ketua Kelompok Tani “Subur 4” juga mengungkapkan hal yang sama:

"Iyah kita sebar ke kalau anggota kelompok dak ini mengikuti pertemuannya kebetulan saya berdua ya kita sebarilah ke anggota. dipakek atau tidaknyakan yang penting kita sudah turunkan ilmunya. Kita pakai bahasa bugis bahasa 
Andi Junudu, Muhammad Rum, Wenny Dastina: Literasi Informasi Petani Nanas

dalam Meningkatkan Produktivitas Pertanian di Desa Tangkit Baru Kec. Sungai Gelam

Kab. Muaro Jambi

kita, saat ketemulah saat-saat rapat setiap rutinnya setiap bulan."( Wawancara:

Bunga Rosi 16 Februari 2020)

Yoyong Maris Ketua Kelompok Tani “Mappakengka” mengungkapkan:

"Kita ya pertemuanlah samo-samo anggota dibahaslah disitu, paling tidak kalau emang kita dak sempat ya didesalah kita. Ketika ada undangan disitu kan paling idak itulah saling meyampaikan informasilah. Komunikasi tukan ya ketika kita ada pertemuan itulah dikomunikasikan langsung, ya salah satu contoh ya kita ada obat yang bagus ni kita diskusilah.” (Wawancara: Yoyong Maris 16 Februari 2020)

Ambo Unang Anggota Kelompok Tani "Berkah Bersama" mengungkapkan: "Ya kalau sudah dipraktekkan ternyata berhasil ya saling berbagi sama teman yang lain supaya sama-sama menghasilkan nanas yang terbaiklah. Paling kalau setiap ada acara, acara-acara pengantin kegiatan-kegiatan olahraga saling ngumpul-ngumpul ha disitulah kadang sharing sama kawan cak mano nanasnyo kok biso bagus sementara nanas sayakan kurang subur."( Wawancara: Ambo Unang 16 Februari 2020)

Andi Uswat Rasik Ketua Kelompok Tani "Karre"” mengungkapkan:

"Informasinya ya disebarkan, terkadang kalo lagi ngumpul sama kawan, rapat kelompok tani walau tidak ada waktu yang ditentukan."( Wawancara: Andi Uswat Rasik 1 Maret 2020)

Berbeda dengan pendapat informan berikut yang menyatakan bahwa informasi yang telah didapatkan kerap kali hampir tidak untuk disebarkan melainkan hanya kepada sesama temannya saja atau yang sepemahamannya saja. Seperti yang diutarakan oleh Baso Husni Anggota Kelompok Tani "Siturue":

"Iya, temen-temen yang bisa di ajak kerjasamalah. Misalnya ketemu di suatu tempat, lagi bahas soal nanas, barulah dikeluarkan, ya ngobrol santailah."( Wawancara: Baso Husni 10 Februari 2020)

Amirullah Ketua Kelompok Tani "Berkah Bersama” mengungkapkan: 
Andi Junudu, Muhammad Rum, Wenny Dastina: Literasi Informasi Petani Nanas

dalam Meningkatkan Produktivitas Pertanian di Desa Tangkit Baru Kec. Sungai Gelam

Kab. Muaro Jambi

"Ndak juga sih karena kawanpun pasti tau juga nanti, lebih memahami juga dak payah disebarkan itu pasti tau dia. Ha inilah kalau lagi istirahat dudukduduk ha ngobrol-ngobrol sambil kawan ni kan nengok kebun kita kawan ni bertanya kita kasih tau dak mesti harus rapat tok nian nggak.” （Wawancara: Amirullah 16 Februari 2020)

Dari beberapa informan, sebanyak 11 informan mengungkapkan informasi yang didapatkan disebarkan dan dikomunikasikan untuk menimbulkan kebersamaan dan kesadaran gotong royong, serta proses penyebaran dan pengkomunikasian informasi dilakukan di waktu istirahat, kumpul bersama teman-teman sesama petani, pada rapat anggota kelompok tani maupun pada pertemuan tatap muka yang tidak disengaja. Walau ada informan lainnya yang tidak memiliki kesamaan pemahaman, namun pemahaman dua informan diatas tidak menyebarkan informasi yang didapatkan memiliki alasan lain yakni untuk meminimalisir timpang tindihnya informasi yang disebarkan. Akan tetapi, jika ada petani yang bertanya seputaran bertani nanas tetaplah dikomunikasikan dengan baik.

Menggunakan informasi berhubungan dengan bagaimana menemukan sebuah cara untuk mengkomunikasikan, menyajikan, dan menggunakan informasi dengan baik serta mampu mengaplikasikan informasi yang ditemukan. Penerapan informasi dilakukan apabila informasi telah ditemukan dan dievaluasi dalam pemilahan dan pemilihan informasi yang nantinya akan memberikan manfaat bagi masyarakat. Informasi yang bermanfaat apabila di sebarkan serta mampu mengkomunikasikannya dengan baik, maka akan berdampak baik pula bagi masyarakat lainnya.

Informasi yang telah ditemukan kemudian di pilah yang seterusnya dievaluasi sebelum diterapkan adalah informasi yang tentunya memiliki manfaat. Penerapan informasi yang dilakukan petani nanas di Desa Tangkit Baru ada yang secara langsung dan ada pula yang melalui penyeleksian terlebih dahulu.Persoalan mengkomunikasikan informasi terletak pada kepribadian petani itu sendiri, mampukah petani untuk bersosialisasi dengan sesama petani lainnya atau malah 
Andi Junudu, Muhammad Rum, Wenny Dastina: Literasi Informasi Petani Nanas

dalam Meningkatkan Produktivitas Pertanian di Desa Tangkit Baru Kec. Sungai Gelam

Kab. Muaro Jambi

sebaliknya. Pemahaman akan pentingnya menyebarkan dan mengkomunikasikan informasi dengan baik, sangatlah dibutuhkan karena dapat memberikan manfaat sesama petani demi kesejahteraan bersama.

Petani Nanas di Desa Tangkit Baru memiliki kemampuan menggunakan informasi yang dapat dikatakanbaik, terbukti dari informasi yang didapatkan, disebarkan dan dikomunikasikan untuk menimbulkan kebersamaan dan kesadaran gotong royong, serta proses penyebaran dan pengkomunikasian informasi dilakukan di waktu istirahat, kumpul bersama teman-teman sesama petani, pada rapat anggota kelompok tani maupun pada pertemuan tatap muka yang tidak disengaja. Semangat gotong royong yang telah ditanamkan oleh pendiri Desa Tangkit Baru inilah yang membuat nilai-nilai kebersamaan tumbuh hingga saat ini. Dan sangat berdampak terhadap perkembangan kesadaran berliterasi informasi dengan baik yang menimbulkan efek positif bagi seluruh petani nanas yang ada di Desa Tangkit Baru.

\section{PENUTUP}

Berdasarkan pembahasan dan pemaparan di atas menunjukkan bahwa; pertama, Kemampuan Petani Nanas di Desa Tangkit Baru dalam mengakses informasi dapat dikategorikan baik, ini dapat dilihat dari informasi yang didapatkan melalui sosialisasi atau bertukar fikiran sesama petani lainnya serta terdapat pula informasi yang didapatkan melalui keluarga dalam hal ini secara turun temurun. Dan rata-rata petani menerapkan informasi yang didapatkan secara langsung diterapkan, ini memberikan arti bahwa petani nanas di Desa Tangkit Baru adalah pelaku praktisi pertanian.

Selanjutnya, Kemampuan Petani Nanas di Desa Tangkit Baru dalam mengevaluasi informasi dapat dikatakan telah optimal. Ini dapat dilihat dari para petani nanas yang rata-rata mengetahui jenis tanaman nanas yang ditanam, mengetahui akan faktor penghambat dalam mencari informasi secara signifikan yang tidaklah sulit, serta kemampuan membandingan informasi yang didapat dan seterusnya dievaluasi 
Andi Junudu, Muhammad Rum, Wenny Dastina: Literasi Informasi Petani Nanas

dalam Meningkatkan Produktivitas Pertanian di Desa Tangkit Baru Kec. Sungai Gelam

Kab. Muaro Jambi

sehingga informasi dapat bermanfaat. Membandingan informasi menurut petani nanas di Desa Tangkit Baru rata-rata dilakukan dengan cara yang berbeda-beda seperti, praktik langsung dilapangan dengan perbandingan hasil tanam, perawatannya yang baik, kemudian ada pula yang menyaring informasi yang terbaik terlebih dahulu kemudian diterapkan. Namun kesemuanya memiliki kesamaan tujuan yakni meraup hasil yang terbaik dan menggunakan waktu yang ringkas. Serta yang terakhir, Kemampuan Petani Nanas di Desa Tangkit Baru dalam menggunakan informasi sudah sangat baik, dilihat dari para Petani Nanas yang langsung menerapkan informasi yang didapatkan dengan percobaan terlebih dahulu, serta informasi yang didapat disebar dan dikomunikasikan untuk menimbulkan kebersamaan dan kesadaran gotong royong. Sehingga tidak diherankan jika petani nanas di Desa Tangkit Baru yang seyogyanya hanya pada tingkat pendidikan rata-rata SMP/SLTP mampu bertani nanas dengan baik, ini dikarenakan adanya peranan penting literasi informasi di tengah masyarakat petani nanas di Desa Tangkit Baru. Sehingga berdampak kepada peningkatan produktivitas pertanian secara optimal.Dengan adanya praktik literasi informasi pada lingkungan masyarakat petani nanas di Desa Tangkit Baru, tentunya produktivitas nanas semakin meningkat dan meminimalisir kerusakan pada lahan pertanian nanas serta menjadikan masyarakat petani nanas di Desa Tangkit Baru sebagai pembelajar seumur hidup.

\section{DAFTAR PUSTAKA}

Abidin, A. Z. (2017). Tangkit Baru Membangun: Geliat Tanpa Henti Menuju Tahun 2022. Muaro Jambi: Kepala Desa Tangkit Baru Periode 2016-2022.

Agustian Widya Gunawan, D. (2018). 7 Langkah Literasi: Knowledge Management. Jakarta: Universitas Atma Jaya.

Eisenberg, M. (2004). Information Literacy: Essetial Skill The Information Age. London: Libraries Unlimited.

Kadir, A. (2003). Pengenalan Sistem Informasi. Yogyakarta: Andi.

Lau, J. (2006). IFLA, : Guidlines in information literacy for lifelong learning. Mexico. 
Andi Junudu, Muhammad Rum, Wenny Dastina: Literasi Informasi Petani Nanas

dalam Meningkatkan Produktivitas Pertanian di Desa Tangkit Baru Kec. Sungai Gelam

Kab. Muaro Jambi

Mentari, A. (2014). Literasi Informasi Politik pada Masyarakat di tempat Pemungutan Suara Desa Simpang Sungai Duren Kabupaten Muaro Jambi . Jambi: Universitas Negeri Sulthan Thaha Saifuddin Jambi.

Nasution, L. F. (2010). Literasi Informasi Mahasiswa Program Studi Ilmu Perpustakaan (S.1). Dipetik Mei 1, 2019, dari http://repository.usu.ac.id bitsream 12345678913518110600255.Pdf

Pattah, S. H. (2013). Perpustakaan dan Literasi Informasi. Jakarta: Gramedia.

Pshycology. (2008). Manfaat Literasi Informasi. Diambil kembali dari https://www.pshycologymania.com/2012/12/manfaat-literasi-informasi.html

Rodin, R. (2016, Desember). Evaluasi Kemampuan Literasi Informasi Pemustaka Perpustakaan Stain Curup Menggunakan Standar yang Dikembangkan ACRL. Al-Maktabah, 15.

Rodiyah, U. (2017). Literasi Informasi dan Peran Perpustakaan dalam Meningkatkan SDM. Bandung : Kencana.

Rum, M. (2017, September). Pemanfaatan Internet sebagai Media Akses Information dalam Kontek HMC (Handphone Mediate Communication) di kalangan Mahasiswa UIN STS Jambi. Baitul 'Ulum, 1(1), 10.

Septiyantono, T. (t.thn.). Konsep Dasar Literasi Informasi Modul 1. Dipetik Desember 8, 2019, dari http://repository.ut.id/4198/PUST4314-M1.Pdf

Sudanwari, M. (2018 , Februari 1). Membangun Budaya Literasi bagi Suplemen Pendidikan di Indonesia. Dikdas Bantara, 1(1).

Tamburaka, A. (2013). Literasi Media: Cerdas Bermedia Khalayak Mdia Massa. Jakarta: Grafindo Persada. 